Historical learning in the design of WTO rules: the EC sugar case

Robert Ackrill* and Adrian Kay**

* Corresponding Author. Division of Economics, Nottingham Business School, Nottingham Trent University, Burton Street, Nottingham, NG1 4BU, UK. T: 0115 848 4234. E: robert.ackrill@ntu.ac.uk.

** Department of Politics and Public Policy, Griffith Business School, Griffith University, Nathan Campus, 170 Kessels Road, Nathan, Brisbane, Queensland 4111, Australia. T: 006173735 7722. E: a.kay@griffith.edu.au. 


\title{
Historical learning in the design of WTO rules: the EC sugar case
}

\begin{abstract}
The Uruguay Round agreement saw significant changes made to the way in which international trade was governed. Trade rules and dispute settlement mechanisms were altered and a series of specific agreements provided for liberalisation across economic sectors. The Agreement on Agriculture, arguably the most difficult and contentious to negotiate, permitted the continued use of trade distorting instruments, both domestically and at the border. Rule-enforcement in agriculture therefore relies crucially on the clarity of the rules. This paper provides an in-depth study of a unique and critical case for understanding the new rules: the EC sugar regime. This policy was challenged unsuccessfully under the pre-Uruguay Round rules, but successfully under the new rules. The sugar case is particularly valuable as the policy was essentially unchanged and the challenges addressed the same concern - excessive export subsidisation. Drawing on primary and secondary materials and interviews with key policy actors, this case is used to illustrate how those involved in the multilateral process learned from particular rule weaknesses revealed in earlier cases, to revise those rules in the Uruguay Round in such a way that dispute panels can more readily and objectively determine rule breaches.
\end{abstract}

\section{Key Words}

EC sugar regime; policy learning; trade rules; Uruguay Round 


\section{INTRODUCTION}

The European Communities’ (EC ${ }^{1}$ ) Common Agricultural Policy (CAP) has been reformed extensively since 1992, but until 2005 its sugar regime had remained fundamentally unaltered. A key catalyst for the timing and shape of this reform was a successful challenge in the World Trade Organisation (WTO) by Australia, Brazil and Thailand, inducing significant reform in a sector previously resistant to change. What makes the EC sugar case both unusual and particularly information rich is that the regime also faced actions in 1978, under the General Agreement on Tariffs and Trade (GATT). Given both the EC policy and complainants’ principal policy concern were essentially the same in both periods, sugar offers a unique opportunity for comparative historical analysis, allowing us to isolate as far as possible the influence of the Uruguay Round Agreement (URA) on agricultural trade dispute settlement. ${ }^{2}$

The purpose of this paper is to examine how, through the act of dispute settlement, weaknesses in trade rules manifested themselves, how those trade rules were changed and, as a result, how these changes have affected the ability of the WTO to make determinations in disputes, with the present paper paying particular attention to the rules pertaining to export subsidisation. The focus on agricultural products is also significant: in contrast to industrial goods, the WTO still permits such trade-distorting interventions in agricultural markets. The rules must therefore be capable of allowing breaches of the limits to such intervention to be determined. This

\footnotetext{
${ }^{1}$ The World Trade Organisation (WTO), for legal reasons, uses the term European Communities rather than European Union. Since the primary policy focus of the present paper is the challenge to the EC sugar regime made in the WTO, the term EC is used throughout for simplicity.

${ }^{2}$ Chile twice brought actions against EC restrictions on apple imports, but both (in 1979 and 1988) were under pre-Uruguay Round rules.
} 
paper, therefore, focuses on trade rules and trade policies, rather than the detailed mechanisms of dispute settlement (see, inter alia, Cameron and Campbell, 1998).

We present an in-depth case study of the challenges against the EC sugar regime based on analysis of primary and secondary documents and a series of interviews with key actors. Case study methods have enjoyed a recent revival in interest in qualitative research methodology as valid and useful tools for the analysis of complex causation in historical sequences, which include rare events and where there are strong interaction effects between variables (Flyvbjerg, 2001; George and Bennett, 2005; Bennett and Elman, 2006 and 2007).

Sugar is a critical case study for understanding the development of agricultural trading rules after the Uruguay Round (UR): as a single, powerful case it permits deductions to be made about the larger phenomenon of the international governance of agriculture in the WTO. Indeed, the fieldwork interviews reported in this paper reveal that the complainants viewed a successful challenge as being of strategic importance to the general issue of how trading rules work in agriculture postUR. The 2002 sugar case was thus an important early case which held the possibility, even if the WTO does not operate on a common law basis, of creating precedence effects and clarifying the meaning of the Uruguay Round Agreement on Agriculture (AoA). ${ }^{3}$ The two sugar actions from 1978 are also important for their rarity; the GATT was asked only on three other occasions to rule on Article XVI:3 and export subsidies (see below). One of these cases occurred very early in the history of the GATT, whilst the other two, coming immediately before the start of the Uruguay Round, had their Panel reports blocked by one or other of the Parties.

\footnotetext{
${ }^{3}$ See Kireeva and O’Connor (2005) for an overview of this issue.
} 
We infer three important lessons from the case study that are of broader relevance to the international governance of agricultural trade. First, there are separable but linked institutional developments in the UR in the WTOs governance of agricultural trade liberalisation. The case study reveals complex and contingent intertemporal interactions and feedback between dispute outcomes, agreement on trade rules and trade liberalisation, and subsequent disputes.

Second, the UR does not mark the culmination of a process of legalisation in agricultural trade. In particular, the sugar case reveals the continued role of political bargaining, from the selection of the case by the complainants to negotiations over EC compliance with the decision. Third, the case casts light on the effect of institutional change on the strategies of WTO member states in trade liberalisation negotiations. This allows us, from a neo-institutionalist perspective, to adumbrate how WTO institutional change might shape trade liberalisation outcomes in the contemporary international governance of agricultural trade.

Section 2 analyses the basis for and timing of the $2002^{4}$ action. Section 3 puts this into comparative historical context by examining the earlier sugar cases, isolating the elements of the URA crucial to understanding the different outcomes. Section 4 teases out the critical elements of institutional change in the WTO for the contemporary international governance of agricultural trade. Section 5 concludes.

\footnotetext{
${ }^{4}$ Australia and Brazil requested consultations in September 2002 (WTO, 2002a and 2002b). Thailand made its request in March 2003 (WTO, 2003a). Coordinated requests for the establishment of a Panel came in July 2003 (WTO 2003b; 2003c; and 2003d). This paper dates the start of the case (referred to in the singular) to the first formal contact with the WTO. Separate documents are available under each case number: 265 (Australia), 266 (Brazil) and 283 (Thailand). Except where indicated, full details will be given just for documents relating to case 265 .
} 


\section{THE 2002 CHALLENGE TO THE EC SUGAR REGIME}

\section{a. Key Features of the EC Sugar Regime}

The basis of EC support was high prices, but on output limited by quota. This was split into ' $\mathrm{A}$ ' and ' $\mathrm{B}$ ' quota and allocated to member states, who assigned it to individual producers. However, the total of A and B-quota contained an in-built surplus which, since 1974/75, has varied between about 1.5 and 4 million tonnes. An intervention price was set for white sugar, of which processors had to pass $58 \%$ to producers. A Basic Price was then derived for beet, with prices for A and B-quota beet production based on this. Production in excess of quota ('C' sugar) had to be exported and was not eligible for an export subsidy.

In terms of the politics of CAP reform, the sugar regime never had the budgetary impact of other commodities because, in 1981, a co-responsibility levy was imposed on producers to cover the cost of export subsidies. The levy has usually been $2 \%$ of the intervention price on A-quota sugar, and a percentage on B-quota sugar that could rise as necessary, up to a ceiling (that changed over time) to cover the balance of subsidy costs.

A further dimension to the EC sugar regime resulted from the accession of the UK in 1973. It had, under the Commonwealth Sugar Agreement (CSA), given preferential access to its (deficit) market to cane-based raw sugar from Australia and several developing countries. The CSA expired in 1974, but pressure from commonwealth countries and the principal refiner of the imported raw sugar, Tate and Lyle, saw the UK negotiate a deal granting the developing countries (but not Australia) preferential access to the EC market. Moreover, the EC guaranteed to buy the sugar at the intervention price. This formed the Sugar Protocol of the Lomé Convention in 1975, a trade agreement with the African, Caribbean and Pacific (ACP) 
group of developing countries. By then, however, the EC was self-sufficient so, ever since, an equivalent quantity of sugar has been sold back onto the world market with subsidy. These exports, as well as the imports, have been treated as a development policy, separated from other sugar transactions and budgetary costs.

\section{b. The Basis and Timing of the Challenge}

In late 2002 Australia and Brazil, joined in early 2003 by Thailand (henceforth ABT), began a joint action against the EC sugar regime. ABT are, along with the EC, the world's largest sugar exporters. The WTO Panel found against the EC in October 2004. Following an appeal by the EC, this decision was upheld in all significant respects by the Appellate Body (AB) in April 2005 (WTO 2004 and 2005). The EC agreed a reform of the sugar regime in November 2005, having published an outline reform package in July 2004 but draft legislation only in June 2005 (European Commission 2004 and 2005).

The essence of the case was simple: the EC was subsidising sugar exports in excess of the volume and expenditure limits set down in the Uruguay Round commitments. The excess had two distinct sources - C sugar exports and ACPequivalent exports - both of which the EC had excluded when establishing its commitments schedule. With C sugar, the ABT argument was that these exports were being cross-subsidised from the high support granted to A and B-quota sugar. The ACP-equivalent exports, in contrast, had always openly been subsidised. A finding against the EC would have profound implications: with no facility to re-negotiate export subsidy commitments ex post, the failure to include these quantities in the commitments $a b$ initio would mean the EC could not simply reduce them by the $21 \%$ 
agreed in the Uruguay Round - it would have to eliminate them totally or reduce domestic A and B-quota production by an equivalent amount.

The URA consists of multiple elements locked into a 'Single Undertaking'. Thus the requests for consultation were based on alleged breaches of several Articles from different elements of the URA. From the AoA, Articles 3.3 and 8 require Members to respect the export subsidy quantity and expenditure limits specified in their schedules. Articles 9.1 and 10.1 then establish the subsidies subject to reduction under the export commitment - the latter doing so by reference to consequence rather than instrument. Australia also identified Article 11, subsidies paid on incorporated products.

Articles 3.1 and 3.2 of the Subsidies and Countervailing Measures (SCM) Agreement were also called upon. These prohibit the use of subsidies awarded contingent on export performance, except as permitted under the AoA. ABT ‘doubled-up' with the AoA and SCM because, if successful, swifter compliance is possible under the SCM than AoA ("without delay" rather than within a "reasonable period of time" - the latter term being from Article 21 of the Dispute Settlement Understanding (DSU)). ${ }^{5}$ ABT also referred to Article XVI of the GATT (subsidies); and Article III:4 (“national treatment”), given that some subsidies were available to processors only on sugar derived from EC-produced cane or beet.

Consultations were held with Australia and Brazil in November 2002 and with Thailand in April 2003. These failed to yield a satisfactory result so, in July 2003, ABT issued coordinated requests for a Panel to be established. These referred to the

\footnotetext{
${ }^{5}$ The Panel chose not to consider the SCM issues, for reasons of 'judicial economy'. The AB criticised the Panel for this, as it denied ABT a possible resolution, but the AB lacked the information to reach a decision themselves (WTO, 2005, pp. 113-118).
} 
principal Articles of the AoA and SCM mentioned above, but no longer mentioned Articles III:4 and XVI of GATT 1994, nor Article 11 of the AoA. The net tends to be cast wide in consultations, as matters not covered there cannot then be introduced into panel requests. More significantly, a tactical decision was taken to focus the panel case on the central issue of export subsidies. Some of the other concerns would have been burdensome on the complainants and Panel for limited commercial reward. A successful challenge on export subsidies, however, would be sufficient to put pressure on the EC to reform its domestic support. ${ }^{6}$

Several factors explain the timing of the challenge. EC sugar exports had risen, rather than fallen, since the conclusion of the UR, with world prices falling as a result. The EC had even "boasted" ${ }^{7}$ in their documents about not having to make cuts. However, Article 9.2(b) of the AoA allowed for some shifting of subsidised exports between years during the "implementation period" 1995-2000, so it was only after this that definitive judgements could be made on subsidised export quantities and expenditures. A further factor was analytical. Cross-subsidisation was known about earlier (see, inter alia, BAE, 1985, pp. 199-201) but it had been assumed that C sugar could have come from the most efficient EC producers who were capable, at the margin, of producing and exporting profitably. ${ }^{8}$ It was only with more recent analytical developments (see Rose, 2004) that a rigorous basis for pursuing such a case emerged.

A third factor was the time taken to coordinate the challenge. There were strong cross-country contacts from the outset, with ABT all members of the Cairns

\footnotetext{
${ }^{6}$ Correspondence with senior Australian government official, Canberra, 20 November 2007.

${ }^{7}$ Interview with senior Australian officials, Canberra, 30 October 2007.

${ }^{8}$ Interview with senior Australian officials, Canberra, 30 October 2007.
} 
Group and the Global Sugar Alliance (GSA). The GSA, based in Australia, was launched at the Seattle WTO Ministerial in 1999 to pursue sugar trade liberalisation through the WTO, although initially it was envisaged that the multilateral talks expected to start in Seattle would be the principal channel for this. ${ }^{9}$ The Brazilian industry was the first to suggest that the EC policy could be vulnerable to a challenge, in response to which the Australian industry approached their government to consider the merits of a case. In the run-up to the action, however, key work was undertaken among senior diplomats. ${ }^{10}$

The domestic process behind the decision to pursue the sugar case was slightly different in each country. In Australia, the industry and government worked closely in preparing the case, as they were to do throughout, with the industry providing market information and technical assistance. Indeed Rose (2004), commissioned to assist the Australian government over the question of cross-subsidisation of C-sugar, draws on a report from an economic consultancy commissioned and funded by the Australian sugar industry for the purposes of this action. Australia were the first to be ready to go to the WTO: there was then a sense in Canberra that they were having to wait for the other countries to prepare.

In Brazil, the evolution was rather different. ${ }^{11}$ Again, there were close links between industry and government - indeed, with the Ministry of Foreign Affairs $(\mathrm{MRE})^{12}$ lacking a budget to pursue cases, finance had to come from the sugar industry. Crucial to the Brazilian approach is the role of the MRE in judging when an

\footnotetext{
${ }^{9}$ Interview with senior Australian sugar industry official, Brisbane, 13 November 2007.

${ }^{10}$ Interview with senior Brazilian trade diplomat, 14 November 2007.

${ }^{11}$ Interview with senior Brazilian trade diplomat, 14 November 2007.

${ }^{12}$ Ministério das Ralações Exteriores.
} 
“issue” becomes a "case” - something they have developed a strong reputation for given their success in the cases pursued. At this time, however, Brazil was also preparing a case against US cotton policy. It was a deliberate tactic that the requests for consultation should go in together. The concern was that if one case started first and suffered a setback, that would have implications for the credibility of the other, its individual merits notwithstanding. Thus Brazil, in effect, kept Australia waiting until it was ready to move on both cases.

An interesting aspect of the development of the Brazilian case was the role of Oxfam and their work on EC sugar policy. Oxfam (2002a) had recently been published and, through regular dialogue, Brazil was aware of, for example, the crosssubsidisation of C-sugar (see also Oxfam 2002b and 2004). This was part of the casebuilding in Brazil, a role Oxfam was also aware of. ${ }^{13}$ In Australia, the work of Oxfam did not have the same role in shaping the action, but it was still important for their case, being "of substance” and by a development agency. Australia made it clear throughout the case they were not challenging the preferential imports of the Sugar Protocol, but were concerned rather with EC exports, something that also affected developing countries and from whom Australia "got a lot of support" during the case. Indeed several developing countries joined the case, on both sides, as Third Parties. Oxfam (2002a) and (2004) were both submitted as exhibits during the investigation (WTO, 2004, pp. 201-202).

The outcome of an earlier action, brought by the US and New Zealand against Canadian dairy exports also helped clarify the sugar case. One issue this case dealt with was to confirm that an element of production, seen by ABT as fundamentally the same in policy terms as C-sugar, was being cross-subsidised on export by high

\footnotetext{
${ }^{13}$ Interview with senior Oxfam Policy Advisor, Oxford, 14 August 2007.
} 
support on other production - that is, such a policy structure did generate 'subsidisation' consistent with the AoA and URA.

\section{c. The EC Reform}

The EC, as noted above, put forward a plan for reform of the sugar regime in 2004, but it was only after the AB report that the legal texts were finalised and published. The key finding of the Panel and AB Reports was that all EC sugar exports were relevant for the export subsidisation commitments; 1.273 million tonnes of sugar and €499.1 million for the export subsidy costs. Having excluded C-sugar exports and ACP-equivalent exports from their export commitments, the EC was now faced with the prospect of having to reduce total sugar exports by 73\% from their base levels (European Communities, 2004a, p. 67).

Furthermore the EC market would be faced with additional pressures in coming years. The 'Everything But Arms' (EBA) trade agreement would allow the 49 Least Developed Countries (LDCs) to export sugar to the EC without barriers from 2009. In addition, motivated in part by the need periodically to get a WTO waiver for the non-reciprocal Cotonou Agreement (the successor to Lomé), the EC is moving its trade agreements with the ACP to the Economic Partnership Agreement (EPA) model of (reciprocal) bilateral free-trade areas, as used with other third countries. The key consequence of this change for the present paper is the abandonment of the Sugar Protocol. In its place participating ACP countries would, after a transition period (current negotiations suggest 2015), also have barrier-free access to the EC market but at lower prices and without a guaranteed buyer. Thus all EBA and EPA imports would be on a commercial basis. 
Given these pressures, high internal prices could not be sustained. Such prices would draw in larger quantities of sugar from developing countries, require direct controls on C-sugar production and still need large cuts in domestic quota levels. Price cuts would reduce the incentives for C-sugar production internally and limit the soon-to-be unfettered developing country imports. The centre-piece of the reform was, therefore, a 36\% cut in support prices, to be phased in over four years from 2006/07. EC producers will be compensated about $64 \%$ of this cut through changes to Single Farm Payments. Limited compensation is also available to ACP producers, whose production and returns on sales to the EC will fall.

There is also a complex structure of incentives and compensation measures for quota retirement, funded via quota levies on those producers and processors who do not retire quota. This was intended as a voluntary scheme but, given the tight timeframe from agreement on reform (November 2005) to publication of the legal texts (February 2006), Article 44 was added to the legislation during this period to allow compulsory cuts to be imposed. ${ }^{14}$ The A and B-quota distinction has been removed whilst C-sugar, now called "out of quota sugar" no longer has to be exported. As less efficient producers leave the industry, 1 million tonnes of quota will be made available for more efficient producers to buy. A review is scheduled for 2008, although changes had to be made to the compensation system in September 2007, given the low initial rate of quota retirement.

\section{THE HISTORICAL CONTEXT OF THE 2002 SUGAR CASE:}

GATT CHALLENGES 1978 AND 1982

\footnotetext{
${ }^{14}$ Interview with senior sugar industry official, London, 9 August 2007.
} 
In 1978 as in 2002, a rapid increase in EC exports triggered actions by Australia and Brazil against the EC’s sugar regime (GATT, 1979, p. 30). The earlier actions were brought separately (GATT, 1978a and 1978b) but shared a key point: through the subsidisation of sugar exports, the EC had violated Article XVI:3 of the GATT, which states that when subsidies are used in the export of primary products, they 'shall not be applied in a manner which results in that contracting party having more than an equitable share of world export trade in that product'. In so doing, ‘serious prejudice’ was caused or threatened to the interests of Australia and Brazil.

The Australian representative argued that the original intention of Article XVI had been "to include the concept of maintaining exports at a level higher than would otherwise exist in the absence of the subsidy” (GATT, 1979, p. 3; GATT, 1994, p. 414). ${ }^{15}$ When a subsidy equivalent to \$US403/tonne was offered with the London Daily white sugar price at \$US206/tonne, “it was reasonable to suppose” (GATT 1979, p. 4) EC export volumes were influenced by the subsidy awarded.

Panel reports were published in 1979 on Australia's action (GATT, 1979) and 1980 for Brazil’s action (GATT, 1980 - each report also summarising the discussion in and evolution of the cases). The Panel investigating Australia’s complaint observed that the EC sugar regime had no effective constraints on output, surpluses, entitlement to refunds nor amount of refunds granted. Although the increased EC share of world exports in 1976 and 1977 "was not unusual in magnitude” (GATT, 1979, p. 31), “[i]t was evident that the increase in exports [in 1978] was effected through the use of subsidies” (ibid).

\footnotetext{
${ }^{15}$ Although this introduced a contradiction with Article XVI:3, which expressly allows for subsidies increasing imports, subject to the 'equitable share' condition.
} 
That said, the 1978 International Sugar Agreement (ISA) required member countries, including Australia and Brazil but not the EC, to reduce production and exports to try to stabilise global markets. ${ }^{16}$ In this context the Panel found "difficulties in establishing clearly the causal relationships between the increase in Community exports, the developments of Australian sugar exports and other developments in the world sugar market” (GATT, 1979, p. 32) and thus was forced to admit "that it was not in a position to reach a definite conclusion that these developments had resulted in the European Communities "having more than an equitable share of world export trade in that product”, in terms of Article XVI:3” (ibid).

Nevertheless, the EC export subsidy system had depressed world prices and thus "serious prejudice had been caused indirectly to Australia" (ibid), although the extent of this could not be quantified. Because of its open-ended subsidy arrangements, the EC system also "constituted a permanent source of uncertainty in world sugar markets” (ibid) and thus represented a threat of prejudice. Alleged violation of Article XXIII:1 (nullification and impairment of benefits from GATT) was not considered as "no detailed submission had been made" (ibid) detailing the benefits affected.

For Brazil, exports in 1976 and 1977 had, in general, been affected by outside factors, but not EC exports. On some specific markets where Brazilian and EC exports were in direct competition, there was no "clear and general evidence” (GATT, 1980, p. 29) that displacement had occurred. Like Australia, however, Brazil had suffered serious prejudice. Regarding complaints under Articles XXXVI and XXXVIII (Trade and Development), subsidised EC exports occurred at a time when

\footnotetext{
${ }^{16}$ Brisbane’s Courier Mail reported on 28 June 1979 that about 3 million tonnes of Australia’s cane crop that year was expected to be left in the fields, given over-production relative to ISA limits.
} 
markets were depressed and developing countries were trying, through the ISA, to improve market conditions. The EC "had therefore not collaborated jointly with other contracting parties to further the principles and objectives set forth in Article XXXVI” (page 30).

The ruling against the EC over serious prejudice was regarded initially by Australia as a "huge" ${ }^{17}$ win as the source of the serious prejudice was clear: an EC export subsidy system that destabilised the world market and which had no effective limits on subsidised exports. Thus, soon after the Panel report on Brazil's action was adopted a GATT Working Party was established for discussions between the parties, to explore possibilities for limiting subsidised EC exports (see GATT, 1981a).

The meetings of the Working Party in 1980 and 1981 were characterised by discussion over the merits of various limited EC 'reforms' - modest price rises, no quota increases and, from 1981, the producer co-responsibility levy. Neither Australia nor Brazil accepted the changes as a "meaningful" response to the call to reduce the quantities eligible for subsidy and to make firm commitments on support prices (GATT, 1981a, p. 5). The EC response was that there was no obligation under Article XVI:1 to do either. As for ACP-equivalent exports, the EC was still insisting they were separate from other subsidised exports; the Australian and Brazilian representatives continuing to reject this position. The Australians pointed out (GATT, 1981b, p. 10-11) that virtually all ACP sugar imports were consumed within the UK. It was therefore producers in other EC countries that benefited from the ability to produce and export - with subsidy - the equivalent amount of sugar (see also GATT, 1981e, p. 18).

\footnotetext{
${ }^{17}$ Interview with senior Australian government official, Canberra, 30 October 2007.
} 
The Australian representative argued that failure to act on EC subsidies would mean the GATT would be admitting it "was unwilling to use its influence” to get contracting parties to change policies in order to fulfil their international obligations (GATT, 1981c, p. 14). The New Zealand representative on the Working Group added (page 16) that "this issue constituted the most important agricultural trade problem to come before the GATT since the conclusion of the Multilateral Trade Negotiations, and that the Report of the Working Party recorded a disappointing lack of success of the dispute settlement system.” Australia submitted a draft decision to bring the issue to a close, but the EC would not accept it.

In September 1981, a second Working Party was established to monitor ongoing developments (see GATT, 1981e). The EC was now adamant that the shift to producer-funded exports meant they were now no longer subsidised within the meaning of the GATT (see, inter alia, GATT, 1981d, p. 19; 1982a, p. 4). This argument was based on the interpretative note to Article XVI included in Annex I of the Agreement. Subsidies, within the meaning of Article XVI:3, arise when "wholly or partly financed out of government funds in addition to the funds collected from producers in respect of the product concerned” (emphasis added). If EC payments were not subsidies, the charge of serious prejudice could not apply to the exports on which they were paid. By excluding ACP-equivalent sugar from the discussion, the EC was also avoiding having it aggregated with other sugar exports. Since the former was openly exported with subsidies, combining them would bring the latter within the meaning of the interpretative note (see, inter alia, GATT, 1982a, pp. 5-7).

Ultimately: "The Chairman [of the GATT Council] expressed regret that no satisfactory solution had been reached in this matter. The Council had adopted two Panel Reports; and a series of formal and informal meetings had been devoted to this 
subject. However, the Council had not been able to arrive at a solution satisfactory to all. He suggested that these two cases be closed.......It was so decided" (GATT, 1982c, p. 21, emphasis in original). Even where the Panels had found against the EC on "serious prejudice" - there was not a formal objective way to determine if the EC actions taken had removed the threat of serious prejudice (notwithstanding the legal loophole of producer-funded subsidies).

Two days later the GATT received another request for consultation over the EC sugar regime (GATT, 1982b). This time it was a joint action by ten countries Argentina, Australia, Brazil, Colombia, Cuba, the Dominican Republic, India, Nicaragua, Peru and the Republic of the Philippines (hereinafter the GATT 10) addressing the same elements of Article XVI as the previous actions. After EC prevarication, consultations were held in September 1982 which, like previous discussions, failed to achieve a mutually acceptable outcome (GATT, 1982d, p. 2021).

On this occasion, however, the GATT 10 did not request a Panel, but laid the action to one side. There had been "no real expectation we would be more successful" ${ }^{18}$ than previously; the motivation was more "one of hope" that the EC could be forced to negotiate terms of entry into a new ISA. The current ISA was struggling because, as noted earlier, EC exports were undermining the efforts of the members (including the GATT 10) to support sugar prices by limiting production and exports. As the 1982 case was intended as leverage, it was "unlikely" ever to go to

\footnotetext{
${ }^{18}$ Interview with senior Australian government official, Canberra, 30 October 2007.
} 
litigation. ${ }^{19}$ Furthermore, countries were devoting considerable time and effort to prepare for the November 1982 GATT Ministerial, regarded as the starting point of moves to establish a new GATT Round. From that meeting, “avoiding subsidization seriously prejudicial to the trade or interests of contracting parties” (GATT, 1982e, p. 9) was highlighted as an issue needed addressing. Attention thus turned to what would become the Uruguay Round talks. ${ }^{20}$

\section{INSTITUTIONAL CHANGES IN THE URUGUAY ROUND AGREEMENTS}

The purpose of this section is to trace a link between the key policy issues that arose in the earlier sugar cases, institutional developments in the Uruguay Round and the policy issues from the 2002 sugar case. ${ }^{21}$ It is not suggested the changes agreed in the Uruguay Round were made exclusively as a result of the sugar cases described herein. It is argued, however, that the earlier sugar challenges stand as critical cases for some of the key shortcomings of the pre-Uruguay Round GATT that needed addressing.

Central to the sugar cases was the nature and definitions of export subsidisation. A key stumbling block for the 1978 actions was the meaning of "more

\footnotetext{
${ }^{19}$ At the time Mr Doug Anthony, Deputy Prime Minister and Trade and Resources Minister, linked the case to the failure of the EC to discuss further the issue of serious prejudice caused by their export subsidies (Courier Mail, Brisbane, 6 April 1982).

${ }^{20}$ Also in April 1982, the US requested conciliation over the EC sugar regime. Their concerns were similar, although they also referred to the impact of EC subsidisation on domestic US prices. Like the GATT 10 action, however, this did not go far. See, inter alia, Josling and Tangermann, 2003, p. 219.

${ }^{21}$ For general accounts of the Uruguay Round see, inter alia, Anderson, 1996; Croome, 1999; Schott, 1994; and Wiener, 1995. On agriculture see, inter alia, Davis, 2003; Josling et al., 1996; and Wolfe, 1998.
} 
than an equitable share of world export trade in that product”. It is not the intention of the present paper to discuss the possible interpretations of this ambiguous concept (the arguments used can be seen in the case documents, especially GATT, 1979 and 1980). We do note, however, that the EC and the complainants disagreed even about which notion of trade should be used as a base from which to determine "share": much sugar trade was undertaken through long-term contracts and other special trading arrangements, thus “free” market trade represented a smaller base. The complainants argued for this, but the Panel agreed with the EC that "total" trade should be used.

The Uruguay Round outcome changed the debate fundamentally, by having countries agree schedules of export subsidisation commitments. By defining limits in terms of absolute values of quantity or budget expenditure, the ambiguity over the meaning of “equitable shares” became irrelevant. Indeed, Australia knew going into the Uruguay Round that it was vital to address the shortcomings of Article XVI. ${ }^{22}$ What makes the concept of "equitable shares" so extraordinary can be seen from the earlier quote from GATT, 1979, p. 32, that despite considering all available evidence, the Panel "was not in a position to reach a definite conclusion" over whether the EC had attained "more than an equitable share of world export trade" in sugar. The key term in Article XVI:3 of the General Agreement was so problematic, the GATT Panel charged with interpreting it felt unable to do so.

Subsequently, the GATT Committee on Trade in Agriculture made the interesting comparison that "[l]ike beauty or pornography, determining what is an equitable share of world export trade in a primary product is a difficult matter and subject to the eye of the discriminating beholder" (GATT, 1983, p. 50). Indeed, of the five occasions when GATT Panels were called upon to do so, only on one occasion

\footnotetext{
${ }^{22}$ Interviews with senior Australian government official, Canberra, 30/31 October 2007.
} 
did they reach a decision, in a 1958 action brought by Australia against French exports of wheat and wheat flour (see GATT, 1958, p. 7; Delcros, 2002, pp. 224-225). In contrast to the sugar cases, with the other two cases that came after (US actions against EC exports of wheat flour and pasta - see Josling and Tangermann, 2003, pp. 216-218 for summaries), both Panel Reports were blocked, one by the EC, the other by the US.

The Committee on Trade in Agriculture suggested the key issue was "that subsidies must not only be found to exist, but must be demonstrated to be the factor more important than any other factors taken together, that could account for the subsidizing country's increased share of world export trade” (GATT, 1983, p. 52). In the early case, the panel took a very simple view of this - one the parties accepted; the latter cases saw increasing recourse to debate over the terms of Article XVI:3, notably “special factors” affecting trade and "previous representative period”.

As Josling and Tangermann (2003, p. 214) point out, the record of actions in the GATT based on Article XVI "is of almost total failure to apply any judicial restraint or discipline to the export subsidies in use for farm products”. Croome (1999, p. 92) notes that, in preparing for the Uruguay Round, the Committee on Trade in Agriculture "aimed at establishing conditions "under which substantially all measures affecting agriculture will be brought under more operationally effective GATT rules and disciplines"”. To the extent that GATT Panels could not meaningfully define what constituted equitable market shares, that particular rule was clearly not “operationally effective”.

Another ambiguity related to the nature of subsidies. According to Josling and Tangermann (2003, p. 214), “[t]he issue of what constituted a subsidy was not seriously in doubt” - what caused the problem was the lack of clarity in Article XVI 
on their use with primary products. In the sugar cases, the arguments over subsidytype payments funded fully by producer payments revealed legal, if not policy, doubts over what was a subsidy and a loophole in the interpretative notes to the GATT: who funds the subsidy does not affect the impact of the exports on world markets and, thus, on other exporters.

Article 9 of the AoA now sets out a series of subsidies covered by the commitment. Paragraph (c) identifies "payments on the export of an agricultural product that are financed by virtue of governmental action, whether or not a charge on the public account is involved, including payments that are financed from the proceeds of a levy imposed on the agricultural product concerned”. Thus fully producer-funded payments are now unambiguously 'subsidies'. It should also be noted that disputes even arose over the meaning of 'primary' products. This was addressed in the AoA by the inclusion, in Annex 1, of a list of exactly which commodities and products it covers.

The commitment schedules also had a fundamental impact on the question of ACP-equivalent sugar exports in the 2002 action. In presenting their export commitments, the EC refer to “ACP/India equivalent” sugar in a footnote, where they indicate the commitment entered into "does not include exports of sugar of ACP and Indian origin on which the Community is not making any reduction commitments”. The EC claimed unsuccessfully in the WTO that on the basis of accepted practice in interpreting international law, the footnote is part of the commitment schedule (despite their failure to reduce exports of the relevant quantities up to that point). Both Panel and AB Reports agreed that the quantity referred to in Footnote 1 was outside the quantity committed for reduction and therefore had to be eliminated totally - a 
policy decision made clearer by the use of explicit quantitative commitments as a framework for policy implementation.

On the specific quantities being subsidised, it was noted earlier that as the case progressed, it was helped in the matter of the cross-subsidisation of C-sugar by the action brought against the Canadian dairy regime. It is beyond the scope of the present paper to explore the underlying economics of the argument (see, in particular, Rose, 2004), but it is important to note that, under Article 10:3 of the AoA, it is now the duty of the defendant facing a claim of excessive subsidisation to show that quantities above the ceiling are NOT exported with subsidy, something the EC failed to do. Also, one particular aspect of the EC response to the question of $\mathrm{C}$ sugar is worth noting. From their first written and oral statements to the WTO, made on 11 and 30 March 2004 respectively (European Communities, 2004a and 2004b), they argued (unsuccessfully) that the omission of $\mathrm{C}$ sugar from their commitment was an “excusable scheduling error" and that the complainants were not acting in "good faith" (Article 3:10 of the DSU) by seeking to get the EC, in effect, to eliminate C sugar exports entirely.

In terms of the history of sugar policy, however, it is hard to accept the notion of excusable errors given that the issue and status of $\mathrm{C}$ sugar had arisen in the 1978 cases. Moreover, in their first oral statement (Australian Government, 2004), the Australians pointed out that their Minister for Trade wrote to the Agriculture Commissioner in December 1993 “recording Australia’s expectation that the EU [sic] Schedule of export subsidy reduction commitments should include commitments on all EC export sugar subsidies on sugar” (paragraph 21). They also pointed out (paragraph 26) that even in 1973 the "Commission had identified a problem with ' $C$ ' sugar”. 
One part of the earlier cases that was successful was the determination of “serious prejudice” against the complainants. As noted earlier, however, the feeling of the Australians that this win was "huge" was tempered by the knowledge that even this term is ambiguous: by how much must subsidised exports from one country be reduced in order to remove the actual or threatened "serious prejudice"? Thus the meaning of this term is linked intimately with the meaning of “equitable share”. The AoA, therefore, has expunged "serious prejudice" also (as has the DSU). On the other hand a breach of a country's export commitment, an objective and quantified metric, constitutes a "prima facie....case of nullification or impairment" of a country’s expected benefits from WTO membership (DSU, Article 3.8).

\section{CONCLUSIONS}

The WTO consists of several elements that are separable, but whose operation is inter-linked. The purpose of this paper has been, through the use of case-study methods, to explore the links between trade disputes and changes to trade rules. This has been done with reference to a series of challenges to the EC sugar regime - by Australia and Brazil in 1978 and by Australia, Brazil and Thailand in 2002. Both challenges focused, in particular, on the 'excessive' use of export subsidisation.

EC sugar offers a unique example of a policy, largely the same on both occasions, being challenged under two different sets of rules, before and after the Uruguay Round. Because this particular case study allows for connections to be made across time, shortcomings in the pre-Uruguay Round trade rules can be identified and specific rule-changes highlighted. The analysis has explored how the way in which the trading rules were expressed affected fundamentally the ability of the GATT/WTO to rule on the acceptability or otherwise of the subsidisation. 
It is not being claimed that the rule-changes occurred because of the sugar cases. It is argued, however, that the sugar cases - two of only five in the history of the GATT that made explicit reference to Article XVI:3 and the export subsidisation of primary products - brought specific weaknesses in the rules to the attention of policy makers in the countries concerned. As a result, multiple weaknesses seen in the pre-Uruguay Round rules through the sugar cases, were addressed in the Uruguay Round. Problems faced in those earlier cases led to lessons being learned in the rewriting of trading rules - rules that, through the informal application of case law, continue to be developed and enhanced.

\section{REFERENCES}

Anderson, K. (ed.) (1996), Strengthening the Global Trading System: From GATT to

WTO (Adelaide: Centre for International Economic Studies, University of Adelaide).

Australian Government (2004), Panel established pursuant to Article 6 of the Understanding on Rules and Procedures Governing the Settlement of Disputes. European Communities Export Subsidies on Sugar - WT/DS265. Australia First

Oral Statement. 30 March 2004 (Canberra: Department of Foreign Affairs and Trade).

Bennett, A. and C. Elman (2006), 'Complex Causal Relations and Case Study Methods: The Example of Path Dependence', Political Analysis, 14, 3, 250-67.

Bennett, A. and C. Elman (2007), 'Qualitative Methods: The View from the Subfield', Comparative Political Studies, 40, 2, 111-21.

BAE (1985), Agricultural Policies in the European Community: Their, Origins, Nature and Effects on Production and Trade, Bureau of Agricultural Economics 
Policy Monograph No. 2 (the “Red Book”) (Canberra: Australian Government Publishing Service).

Cameron, J. and K. Campbell (eds.) (1998), Dispute Resolution in the World Trade Organisation (London: Cameron May).

Croome, J. (1999), Reshaping the World Trading System: A history of the Uruguay Round, $2^{\text {nd }}$ edition (The Hague: Kluwer Law International).

Davis, C. L. (2003), Food Fights Over Free Trade: How International Institutions Promote Agricultural Trade Liberalization (Princeton, NJ: Princeton University Press).

Delcros, F. (2002), ‘The Legal Status of Agriculture in the World Trade Organization: State of Play at the Start of Negotiations', Journal of World Trade, 36, 2, 219-53. European Commission (2004) Accomplishing a Sustainable Model for Europe Through the Reformed CAP - Sugar Sector Reform, Communication from the Commission to the Council and the European Parliament, COM(2004)499 final, Brussels.

European Commission (2005) Proposal for a Council Regulation on the Common Organisation of the Markets in the Sugar Sector, COM(2005)263 final, Brussels. European Communities (2004a) European Communities - Export Subsidies on Sugar DS 265, 266, 283, First Written Submission by the European Communities, Geneva, 11 March 2004.

European Communities (2004b) European Communities - Export Subsidies on Sugar DS 265, 266, 283, Oral Statement by the European Communities, Geneva, 30 March 2004.

Flyvbjerg, B. (2001), Making Social Science Matter: Why social enquiry fails and how it can succeed again (Cambridge: Cambridge University Press). 
GATT (1958), French Assistance to Exports of Wheat and Wheat Flour: Report by the Panel for Conciliation, L/924 (Geneva: General Agreement on Tariffs and Trade, 20 November).

GATT (1978a), European Communities - Refunds on Exports of Sugar: Recourse to Article XXIII:2 by Australia, L/4701 (Geneva: General Agreement on Tariffs and Trade, 27 September).

GATT (1978b), European Communities - Refunds on Exports of Sugar: Recourse to Article XXIII:2 by Brazil, L/4722 (Geneva: General Agreement on Tariffs and Trade, 14 November).

GATT (1979), European Communities - Refunds on Exports of Sugar: Complaint by Australia. Report of the Panel, L/4833 (Geneva: General Agreement on Tariffs and Trade, 25 October).

GATT (1980), European Communities - Refunds on Exports of Sugar: Complaint by Brazil. Report of the Panel. L/5011, (Geneva: General Agreement on Tariffs and Trade, 7 October).

GATT (1981a), European Communities - Refunds on Exports of Sugar. Article XVI:1 Discussions - Report to the Council, L/5113 (Geneva: General Agreement on Tariffs and Trade, 20 February).

GATT (1981b), European Communities - Refunds on Exports of Sugar: Article XVI Discussions. Comments by the Representative of Australia, L/5121 (Geneva: General Agreement on Tariffs and Trade, 6 March).

GATT (1981c), Minutes of Meeting held in the Centre William Rappard on 10 March 1981, C/M/146 (Geneva: General Agreement on Tariffs and Trade, 15 May). 
GATT (1981d), Council of Representatives: Report on Work since the Thirty-Sixth Session, L/5245 (Geneva: General Agreement on Tariffs and Trade, 16 November).

GATT (1981e), Minutes of Meeting held in the Centre William Rappard on 22, 23 and 25 September 1981, C/M/150 (Geneva: General Agreement on Tariffs and Trade, 4 December).

GATT (1982a), Working party - Sugar: Report to the Council, L/5294 (Geneva: General Agreement on Tariffs and Trade, 1 March).

GATT (1982b), European Communities - Sugar Regime: Recourse to Article XXIII by [... ], L/5309 (Geneva: General Agreement on Tariffs and Trade, 8 April).

GATT (1982c), Minutes of Meeting held in the Centre William Rappard on 31 March 1982, C/M/156 (Geneva: General Agreement on Tariffs and Trade, 7 May).

GATT (1982d), Minutes of Meeting held in the Centre William Rappard on 1 October 1982, C/M/161 (Geneva: General Agreement on Tariffs and Trade, 29 October).

GATT (1982e), Ministerial Declaration Adopted on 29 November 1982, L/5424 (Geneva: General Agreement on Tariffs and Trade, 29 November).

GATT (1983), Analysis of the Drafting History of Article XVI and of the Work of Past Panels and Working Parties as Regards Subsidies on Agricultural Products: Note by the Secretariat, AG/W/4 (Geneva: General Agreement on Tariffs and Trade, 12 September).

GATT (1994), Analytical Index: Guide to GATT Law and Practice, 6 ${ }^{\text {th }}$ ed. (Geneva: General Agreement on Tariffs and Trade).

George, A. L. and A. Bennett (2005), Case Studies and Theory Development in the Social Sciences (Cambridge, MA: MIT Press). 
Josling, T. and S. Tangermann (2003), 'Production and Export Subsidies in Agriculture: Lessons from GATT and WTO Disputes Involving the US and the EC', in E.-U. Petersmann and M. A. Pollack (eds.), Transatlantic Economic Disputes: The EU, the US, and the WTO (Oxford: Oxford University Press).

Josling, T., S. Tangermann and T. K. Warley (1996), Agriculture in the GATT, (Basingstoke: Macmillan).

Kireeva, I. and B. O’Connor (2005), ‘The Agreement on Agriculture and Dispute Settlement', in B. O’Connor, (ed.), Agriculture in WTO Law (London: Cameron May).

Oxfam (2002a), The Great EU Sugar Scam: How Europe's sugar regime is devastating livelihoods in the developing world, Oxfam Briefing Paper 27, August (Oxford: Oxfam).

Oxfam (2002b), Stop the Dumping! How EU agricultural subsidies are damaging livelihoods in the developing world, Oxfam Briefing Paper 31, October (Oxford: Oxfam).

Oxfam (2004), Dumping on the World: How EU sugar policies hurt poor countries, Oxfam Briefing Paper 61, March (Oxford: Oxfam).

Rose, R. (2004), Sugar in the European Union: sugar production costs and cross subsidies to $C$ sugar exports, Report produced for the Australian Government Department of Agriculture, Fisheries and Forestry.

Schott, J. J. (1994), The Uruguay Round: an assessment (Washington, DC: Institute for International Economics).

Wiener, J. (1995), Making Rules in the Uruguay Round of the GATT: A study of international leadership (Aldershot: Dartmouth). 
Wolfe, R. (1998), Farm Wars: the political economy of agriculture and the international trade regime (Basingstoke: Macmillan).

WTO (2002a), European Communities - Export Subsidies on Sugar. Request for Consultations by Australia, WT/DS265/1 (Geneva: World Trade Organisation, 1 October).

WTO (2002b), European Communities - Export Subsidies on Sugar. Request for Consultations by Brazil, WT/DS266/1 (Geneva: World Trade Organisation, 1 October).

WTO (2003a), European Communities - Export Subsidies on Sugar. Request for Consultations by Thailand, WT/DS283/1 (Geneva: World Trade Organisation, 20 March).

WTO (2003b), European Communities - Export Subsidies on Sugar. Request for the Establishment of a Panel by Australia, WT/DS265/21 (Geneva: World Trade Organisation, 11 July).

WTO (2003c), European Communities - Export Subsidies on Sugar. Request for the Establishment of a Panel by Brazil, WT/DS266/21 (Geneva: World Trade Organisation, 11 July).

WTO (2003d), European Communities - Export Subsidies on Sugar. Request for the Establishment of a Panel by Thailand, WT/DS283/2 (Geneva: World Trade Organisation, 11 July).

WTO (2004), European Communities - Export Subsidies on Sugar. Complaint by Australia: Report of the Panel, WT/DS265/R (Geneva: World Trade Organisation, 15 October). 
WTO (2005), European Communities - Export Subsidies on Sugar. AB-2005-2:

Report of the Appellate Body, WT/DS265/AB/R (Geneva: World Trade Organisation, 28 April). 